\title{
Biological activities of bovine glycomacropeptide
}

\author{
Ernest P. Brody* \\ Land O'Lakes, Inc. PO Box 64101, St Paul MN 55164-0101, USA
}

\begin{abstract}
Biological activity of bovine $\kappa$-caseino glycomacropeptide (GMP) has received much attention in recent years. Research has focused on the ability of GMP to bind cholera and Escherichia coli enterotoxins, inhibit bacterial and viral adhesion, suppress gastric secretions, promote bifidobacterial growth and modulate immune system responses. Of these, protection against toxins, bacteria, and viruses and modulation of the immune system are the most promising applications.
\end{abstract}

Bacterial/viral/toxin adhesion: Prebiotic: Immune system modulation

\section{Introduction}

In recent years, several lines of research have indicated that milk components, particularly those found in whey, have biological activity. Source materials for these studies are usually bovine milk components since they are most common and in largest supply. In particular, the biological activity of bovine $\kappa$-casein or $\kappa$-caseino glycomacropeptide $(\mathrm{GMP})^{\dagger}$ has been studied. The introductory paragraphs recount a litany of physiological functions attributed to GMP, including:

(1) binding of cholera and Escherichia coli enterotoxins;

(2) inhibition of bacterial and viral adhesion;

(3) suppression of gastric secretions;

(4) promotion of bifidobacterial growth;

(5) modulation of immune system responses.

This paper summarizes literature reports of biological activities of GMP. The main focus is studies related to bovine milk GMP, and peripherally $\mathrm{\kappa}$-casein, since that is the most abundant variety available. Bovine colostral GMP and human milk and colostral GMP, although studied in considerable detail, do not present a commercializable source for useful products. This review may provide a springboard for further research which will result in elucidation of additional health benefits of GMP and, perhaps, development of health claims for functional foods and dietary supplements.

\section{Structure of GMP}

When bovine $\kappa$-casein is treated with chymosin during cheesemaking, the protein is hydrolysed into para-к-casein (residues 1-105), which remains with the curd, and GMP (residues 106-169), which is removed with the whey (Eigel et al. 1984; van Hooydonk et al. 1984). The latter, a glycophosphopeptide, is probably the least well known of the cheese whey proteins even though it comprises 15-20 $\%$ of the protein (Saito et al. 1991), as measured by total Kjeldahl nitrogen, from renneted cheese whey. Examination of amino acid sequence of GMP in Fig. 1 reveals possible reasons for its neglect (Eigel et al. 1984; Whitney, 1988). There are no aromatic amino acids in GMP and it is, therefore, invisible at $280 \mathrm{~nm}$, the common protein detection wavelength. In addition, GMP retains a net negative charge, even at $\mathrm{pH} \mathrm{3}$, so it is not collected on cation exchangers, nor does it move with the rest of the proteins in native polyacrylamide gel electrophoresis (PAGE). Its low molecular weight of $8000 \mathrm{Da}$ makes it difficult to visualize with Coomassie Blue stain in sodium dodecyl sulphate (SDS)-PAGE. Quantification procedures for GMP require trichloroacetic acid precipitation of the other whey proteins leaving only the GMP in solution (van Hooydonk \& Olieman, 1982; Sharma et al. 1993).

The amino acid sequences of both $\mathrm{\kappa}$-casein and GMP and their variants have been well defined (Eigel et al. 1984; Whitney, 1988; Fiat \& Jolles, 1989). One current GMP application is in diets for phenylketonuria patients (Nielsen $\&$ Tromholt, 1994). These individuals lack the ability to metabolize phenylalanine making GMP an amino acid source which they can tolerate. Unfortunately, the lack of other essential amino acids (arginine, cysteine, histidine, tryptophan and tyrosine) requires other protein sources in those diets.

Many researchers (Tran \& Baker, 1970; Fiat et al. 1972; Jolles et al. 1973; Fournet et al. 1975, 1979; Doi et al. 1979; van Halbeek et al. 1980; Saito et al.1981; Saito \& Itoh, 1992) contributed to information about the saccharide structures in GMP. In mature cow milk it has been established that five saccharides are found:

(1) monosaccharide GalNAc - O - R

(2) disaccharide Gal $\beta 1 \rightarrow 3$ GalNAc - O - R

\footnotetext{
* Corresponding author: E. P. Brody, fax +1 651 481-2002, email ebrod@landolakes.com

'Referred to in this review as glycomacropeptide but also designated caseinomacropeptide and caseinoglycopeptide in the literature.
} 


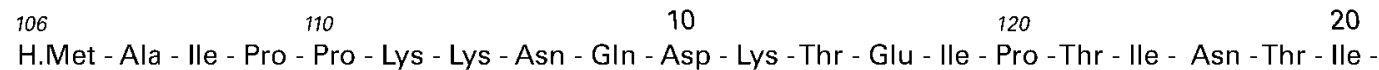

$$
\begin{aligned}
& \text { Ala - Ser - Gly - Glu - Pro - Thr - Ser - Thr - Pro - Thr - } \stackrel{30}{130} \text { Thr]- Glu - Ala - Val - Glu - Ser - Thr - Val - Ala - Thr } \\
& \text { Varient B |lle| }
\end{aligned}
$$

$150 \quad 50 \quad 60$

Leu - Glu - |Asp| - Ser - Pro - Glu - Val - Ile - Glu - Ser - Pro - Pro - Glu - Ile - Asn - Thr - Val - Gln - Val - Thr

Variant B $\mid$ Ala| $P$

64

Ser - Thr - Ala - Val.OH

Fig. 1. Primary structure of bovine GMP variant A. (Eigel et al. 1984; Whitney, 1988). The enclosed amino acid residues are the sites corresponding to mutational differences in the B variant. The small italicized numbers refer to the amino acid residue sequence numbering based upon $\kappa$-casein. Sites of glycosylation and phosphorylation are boldfaced. Note that there are eleven negatively charged and three positively charged amino acid residues.

(3) trisaccharide NeuAc $\alpha 2 \rightarrow 3$ Gal $\beta 1 \rightarrow 3$ GalNAc $\mathrm{O}-\mathrm{R}$

(4) trisaccharide Gal $\beta 1 \rightarrow 3$ (NeuAc $\alpha 2 \rightarrow 6$ ) Gal$\mathrm{NAc}-\mathrm{O}-\mathrm{R}$

(5) tetrasaccharide NeuAc $\alpha 2 \rightarrow 3 \quad$ Gal $\quad \beta 1 \rightarrow 3$ $($ NeuAc $\alpha 2 \rightarrow 6$ ) GalNAc - O - R

where $\mathrm{Gal}=$ galactose,$\quad \mathrm{GalNAc}=N$-acetylgalactosamine, and NeuAc $=$ sialic acid ${ }^{\ddagger}$

Six other saccharides have been delineated in cow colostrum (Saito et al. 1981; Fiat \& Jolles, 1989); $N$ acetylglucosamine (GlcNAc) and fucose (Fuc) have been identified as constituents in these saccharides.

It is important to draw a distinction between bovine and human GMP oligosaccharides. The latter contain no NeuAc and have Gal, GlcNAc, and Fuc as terminal sugars on their oligosaccharides (Fiat \& Jolles, 1989). Of the fourteen human milk GMP oligosaccharides which have been identified, only disaccharide II is found in milk GMP from both species. There is an asialotetrasaccharide which is found in both bovine colostrum and human milk.

The point of saccharide attachment is not uniform, though it is agreed that the glycosidic linkage is through an oxygen and that $\mathrm{R}$ is threonine (Thr) (Eigel et al. 1984; Whitney, 1988; Fiat \& Jolles, 1989). Jolles et al. (1972, 1973) have shown that Thr26 or 28 of the peptide chain (Thr131 or 133 of the $\kappa$-casein chain) bears a saccharide. There is evidence (Kanamori et al. 1980) that Thr30 or 31 (Thr135 or 136 of the $\kappa$-casein chain) also participate. Several reports indicate that multiple saccharide substituents may be linked on a single peptide chain (Doi et al. 1980; Otani et al. 1995). In contrast to this variability, one phosphate moiety in GMP is always at serine 44 (Ser149 of the k-casein chain) (Fiat et al. 1981; Eigel et al. 1984; Whitney, 1988) though non-phosphorylated fractions have been found.

\footnotetext{
Referred to as sialic acid and $N$-acetylneuraminic acid in the literature; the former is used in this review.
}

\section{Preparation of GMP}

Two approaches have been taken for GMP preparation. One approach is preparation of casein or $\kappa$-casein free of whey proteins followed by hydrolysis with rennet to produce GMP. The other approach is purification of GMP directly from cheese whey made by a rennet process.

Using the former approach, Dosako et al. (1991) describe rennet treatment of sodium caseinate to produce a crude GMP preparation. Shammet et al. (1992) showed that small peptides are present. Where more-defined preparations are desired it is necessary to purify $\kappa$-casein by precipitation (McKenzie \& Wake, 1961; Zittle \& Custer, 1963), gel filtration (Yaguchi et al. 1968), or ion exchange (Hollar et al. 1991). Coolbear et al. (1996) compared these methods and determined that the GMPs resulting from the $\kappa$-caseins were virtually identical by reverse-phase chromatography and gel electrophoresis.

When the latter approach is used, the primary challenge is separation of GMP from the other whey proteins. In the laboratory, GMP is prepared by precipitation of the other whey proteins with trichloroacetic acid (Morr \& Seo, 1988; Shammet et al. 1992) or phosphotungstic acid (Eustache, 1977a) followed by dialysis or ultrafiltration.

Several processes (Eustache 1977b; Nielsen \& Tromholt, 1994) call for heating whey protein concentrate (WPC) to temperatures above $85^{\circ} \mathrm{C}$ in order to flocculate the whey proteins, adjusting to the isoelectric point, and separating by centrifugation or filtration. The GMP, which is heat stable, is collected in the supernatant or filtrate. Berrocal \& Neeser (1993) heated WPC at pH 6, with added calcium and $25 \%$ ethanol, to $90^{\circ} \mathrm{C}$. The solution was acidified to $\mathrm{pH}$ 4.5 and flocculent material was removed by centrifugation leaving a supernatant containing GMP.

Ion exchange processes take advantage of the highly negative charge on GMP even at low $\mathrm{pH}$ where the other whey proteins are positively charged. Whey at $\mathrm{pH} 3$ is contacted with a cation exchanger (Shimatini et al. 1993; Kawasaki \& Dosako, 1994). The GMP is not adsorbed by the cation exchanger and may be concentrated and desalted by ultrafiltration. Alternatively, whey at $\mathrm{pH}$ less than 4 is 
contacted with an anion exchanger (Kawasaki et al. 1994). The GMP is adsorbed on the anion exchanger while the other whey proteins are washed free. It is then possible to elute GMP from the ion exchanger. Etzel (1999) employed a copper-containing metal affinity adsorbent as well as a cation exchanger to produce GMP from whey. Until recently ion-exchange processes used very expensive hydrophilic ion exchangers such as cellulose (Shimatini et al. 1993; Kawasaki \& Dosako, 1994; Kawasaki et al. 1994) or silica (Skudder, 1985) based 'resins'. Erdman \& Neumann (1999) used a polystyrene weak anion exchange resin in the alkaline form to capture GMP from an acidified whey solution.

Kawasaki et al. (1993a) using gel filtration with Superose, reported that above $\mathrm{pH}$ 4, GMP exists as tetramers and pentamers but at $\mathrm{pH}$ below 4 GMP exists as monomers and dimers. Using this phenomenon, Tanimoto et al. (1991) carried out ultrafiltration on whey at a $\mathrm{pH}$ below 4 using a sufficiently large-pored membrane. The GMP, in the form of monomers and dimers, was able to pass through into the permeate. Adjustment to $\mathrm{pH}$ above 4 allows concentration by ultrafiltration in the form of tetramers and pentamers with a smaller-pored membrane. There is some question as to whether the observed molecular size change is due to a change in oligomerization. Minkiewicz et al. (1996) used reverse-phase chromatography and determined that GMP, regardless of glycosylation, is a monomer at all $\mathrm{pH}$ values, ionic strengths and concentrations. The large apparent molecular mass was explained by internal electrostatic and steric repulsion. Nakano \& Ozimek (1998) using gel filtration with Sephadex S-200 and G-75 observed that GMP exhibits apparent molecular mass of trimers and observed no change in oligomerization between $\mathrm{pH} 7$ and $\mathrm{pH} 3 \cdot 5$.

\section{Biological activties}

\section{Ability to bind cholera toxin and E. coli enterotoxins}

Cholera toxin produced by Vibrio cholerae consists of an A subunit and five B subunits. The B subunits form the attachment site which binds to oligosaccharides on cell walls. Once bound, the A subunit activates adenylate cyclase in cells which results in loss of cellular water which causes diarrhoea and possibly death (Holmgren, 1981). It has been shown that the receptor is a ganglioside $\mathrm{G}_{\mathrm{M} 1}$ (van Heyningen, 1974), which has the structure Gal $\beta 1 \rightarrow 3$ GalNAc $\beta 1 \rightarrow 4$ (NeuAc $\alpha 2 \rightarrow 3$ ) Gal $\beta 1 \rightarrow 4$ Glc $\beta 1 \rightarrow 1$ Cer (Leeden, 1966) (where Glc $=$ glucose and Cer $=$ ceramide). This oligosaccharide is not identical to GMP, but other glycoproteins such as fetuin and glycophorin which have oligosaccharides similar to GMP inhibit cholera toxin (Sugii \& Tsuji, 1989; Schengrund \& Ringler, 1989).

Kawasaki et al. (1992) have shown that GMP is capable of binding cholera toxin. Normal Chinese hamster ovary (CHO)-K1 cells are spherical. In the presence of cholera toxin, $\mathrm{CHO}-\mathrm{K} 1$ cells take on a spindle shape. As little as 20 p.p.m. GMP is enough to cause considerable rounding of CHO-K1 cells and 100 p.p.m. GMP results in almost completely rounded $\mathrm{CHO}-\mathrm{K} 1$ cells which indicates that
GMP has bound to cholera toxin. When the GMP was treated with sialidase, which hydrolyses the sialic acids, complete loss of cholera toxin inhibiting activity occurred. The peptide chain must also participate in the binding as partial loss of cholera toxin inhibiting activity occurred after treatment with proteases. Worobo et al. (1998) were able to narrow the activity to a peptide fraction obtained by ion-exchange chromatography.

Isoda et al. (1990) carried the work further to other bacterial toxins. They obtained similar inhibitions against E. coli heat labile enterotoxins LT-I and LT-II (associated with colonization factor antigen CFA/I and CFA/II, respectively) in the $\mathrm{CHO}-\mathrm{K} 1$ model. Additionally, the ability of the GMP to protect mice against diarrhoea caused by the toxins was evaluated. Feeding $1 \mathrm{mg}$ GMP per day protected $100 \%$ of the mice against cholera toxin and LTII, and $80 \%$ of the mice against LT-I.

\section{Inhibition of bacterial and viral adhesion}

Many bacteria and viruses bind themselves to their hosts as a part of the colonization process. Binding to the intestine or other mucosal surfaces is achieved by adhesins, capsular material on the bacterial cell surface or hair-like fimbriae or pili which are specific for the various ceramide and ganglioside glycoconjugates which make up epithelial cell membranes (Simon, 1996). Considerable research has been done to characterize the nature of the adhesins and their receptors and it may be possible to find substances which have sufficient similarity to the receptors that they block the receptor and thereby inhibit colonization (Ofek \& Sharon, 1990).

The haemagglutination assay is often used to screen for compounds which prevent bacterial or viral binding to cell receptor sites. The assay detects the ability of the bacterium or virus to bridge between erythrocytes (red blood cells) and cross-link or agglutinate the erythrocytes. If the adhesin is bound to the compound in preference to the receptor site, agglutination will not occur. Thus, haemagglutination inhibition is a sign that the compound has potential to prevent bacterial colonization.

Neeser et al. (1988a) have been investigating the mechanism by which milk components prevent dental caries. They evaluated the role of GMP in inhibiting adhesion of cariogenic bacteria (Streptococcus mutans, $S$. sanguis, S. sobrinus and Actinomyces viscosus) to oral surfaces. Haemagglutination by $S$. mutans, $S$. sanguis and A. viscosus is prevented by GMP with disaccharide II (Neeser et al. 1988a). Using saliva-covered hydroxyapatite beads, as a saliva covered tooth model, binding of bacteria in the presence of GMP was measured. GMP prevented binding of $S$. sobrinus and $S$. sanguis, but not A. viscosus (Neeser et al. 1994). A further proof of binding was obtained using GMP-gold conjugates which could be seen attached to $S$. sanguis bacteria by electron microscopy. A $23 \mathrm{kDa}$ glycoprotein from $S$. sanguis which binds to buccal (cheek) epithelial cells was identified (Neeser et al. 1995). Trisaccharide III is on the glycoprotein. Further, S. mutans and $S$. sobrinus binding to salivary pellicle (the thin layer of salivary protein and glycoprotein which quickly adheres to a freshly cleaned tooth) could be prevented by GMP 
(Schupbach et al. 1996). They believe that the mechanism by which GMP reduces dental caries is by changing the microbial composition of dental plaque from streptococci to less cariogenic Actinomyces. Incorporating GMP in gum or toothpaste is a method of preventing dental plaque and caries (Neeser, 1991a,b). Xylitol and GMP appear to have a synergistic effect in not only preventing caries but also remineralizing teeth (Zhang \& Shapiro, 1998).

Kawasaki et al. (1993b) demonstrated that GMP inhibits haemagglutination by four strains of human influenza virus. As little as 80 p.p.m. was effective. Dosako et al. (1992) found 10 p.p.m. concentrations of GMP prevent EpsteinBarr virus from inducing morphological transformations in peripheral blood lymphocytes.

Bacterial adhesion offers a field ripe for further GMP application, but there are some caveats related to specificities. Neeser et al. (1988b) evaluated GMP as a haemagglutination inhibitor for CFA/I and CFA/II expressing $E$. coli which are associated with the toxins discussed above (LT-I and LT-II). N-linked glycoproteins with trisaccharide III were active, but GMP and other O-linked glycoproteins were not. Thus, GMP inhibits toxin binding but not bacterial binding. There are reports that trisaccharide III prevents haemagglutination of other E. coli strains (Parkkinen et al. 1986; Liukkonen et al. 1992). Also, proteins with O-linked trisaccharide III and tetrasaccharide IV have modest activity in binding of Mycoplasma gallisepicum (Glasgow \& Hill, 1980) and M. pneumoniae (Loomes et al. 1984) which are associated with an autoimmune disorder. There should be evaluations of GMP in these applications.

\section{Suppression of gastric secretions}

A Russian group led by Stan and Chernikov (Vasilevskaya et al. 1977) showed that GMP inhibits gastric secretions and slows stomach contractions in dogs. When dogs were intravenously injected with $10-15 \mathrm{mg}$ of bovine GMP, their gastric secretions became less acidic and motions at the gastric fundus and the duodenum were reduced (Stan \& Chernikov, 1982). Rat derived GMP had the same effect (Vasilevskaya et al. 1977). Further experiments showed that a pepsin digest of GMP produced two active fractions which were separable with Sephadex (Chernikov \& Stan, 1982; Stan et al. 1983). The stronger of these was a 700$2000 \mathrm{Da}$ peptide fraction (Stan \& Chernikov, 1979). Activity of the two fractions was resistant to proteolysis with pepsin, trypsin and chymotrypsin. It was also established that GMP peptides could reduce gastric acid secretions by half and blood serum gastrin levels by $8 \%$ (Aleinik et al. 1986).

Further experiments were carried out in France at the INRA laboratories. Guilloteau et al. (1987) found that intravenous injection of GMP afforded no inhibition of gastric secretions or changes of digestive hormone blood plasma levels in preruminant calves. However, they did find that feeding GMP at levels similar to those experienced in normal feeding resulted in inhibition of gastric secretion during the first and second hour after feeding (Guilloteau et al. 1994). Feeding at five times the normal feeding level resulted in no effect. Beucher et al. (1994b) found that feeding one GMP fraction, stimulated the intestinal hormone cholecystokinin which, in turn, regulates gastrointestinal functions. Non-glycosylated GMP had no effect on the basal cholecystokinin level and B variant (which varies from the A variant by two amino acids) glycosylated GMP had only a slight stimulating effect in the rat (Beucher et al. 1994a). The A variant with a terminal sialic acid (Yvon et al. 1994) exhibited the largest stimulation which indicates that both the peptide chain and the carbohydrate structure are important for stimulating gastric secretions.

Stan et al. (1983) proposed that it is necessary for the GMP molecule to enter the blood in order to cause gastric acid inhibition. Yvon et al. (1994) demonstrated that GMP acts by triggering receptors on the intestinal mucosa.

\section{Promotion of bifidobacterial growth}

Bifidobacteria predominate in the lower intestine and are thought to inhibit pathogenic bacterial growth and thereby afford protection from gastrointestinal diseases (Faure et al. 1984). Gyorgy et al. (1954a) found the first evidence of a bifidobacterial growth promoting factor in human colostrum and human milk. The activity in human milk was about half that of colostrum on a dry weight basis. They also found that bovine colostrum has about one-tenth of the activity and bovine milk has one-hundredth of the activity of human colostrum on a dry weight basis (Gyorgy et al. $1954 b)$. In a search to identify the bifidus factor, Gyorgy et al. (1974) found that GlcNAc and oligosaccharides with terminal GlcNAc promote bifidobacterial growth. Sialidase treatment of $\alpha_{1}$-acid glycoprotein resulted in an increase in bifidobacterial growth and they proposed that this is due to cleavage of the terminal NeuAc exposing a GlcNAc.

Since that time the elusive bifidus factor has been sought in bovine milk in general and GMP in particular. Kehagias et al. (1977) found some bifidobacterial growth promoting activity in a fraction obtained from a sulphuric acid treatment of whole casein. The preparation was ill defined. They had evidence that it was perhaps $\kappa$-casein derived but not similar to GMP. Bezkorovainy et al. (1979) found glycopeptide from a bovine milk casein chymotryptic digest to have one-tenth the growth-promoting activity of human milk solids. Azuma et al. (1985) compared human and bovine GMPs and found that acidity generation with the latter was one-third as large as the acidity generation with the former.

The situation appears to be quite complex with conflicting data which are not favourable to bovine GMP as a specific bifidus growth promoter. Poch \& Bezkorovainy (1988) evaluated several promoter candidates, including bovine casein digest and bovine milk whey, on eight bifidus species. Each of the candidates promoted growth of one or more bifidus species. In further work they showed that any growth-promoting activity of $\kappa$-casein goes with the para- $\kappa$-casein rather than the GMP when rennet-treated $\mathrm{\kappa}$-casein is fractionated (Poch \& Bezkorovainy, 1991). Petschow \& Talbott (1991) reported that growth promoting activity for some bifidus species is present in cow milk ultrafiltration permeate as well as retentate. This would rule GMP out because, as noted 
above, oligomerization prevents GMP from passing through an ultrafiltration membrane except at a very low pH. Research by Proulx et al. (1992) would lead one to believe that the amino acid portion is critical for bifidus growth but (patented) work (Idota, 1996; Yakabe et al. 1994) would favour saccharides containing sialic acid.

\section{Modulation of immune system responses}

Splenocyte (spleen lymphocyte) proliferation is a step in the inflammatory response. Inhibition of splenocyte proliferation can be used to demonstrate suppression of an immune response such as an allergic reaction. Research by Otani et al. (1992) demonstrated that casein inhibits mouse splenocyte proliferation induced by the mitogen Salmonella typhimurium lipopolysaccharide (LPS). Inhibitory activity was due to $\kappa$-casein, which upon rennet hydrolysis, results in inhibitory activity being found in the GMP fraction. Para-к-casein had no inhibitory activity. Upon sialidase digestion, GMP lost its inhibitory activity, indicating that sialic acid is critical to the phenomenon (Otani \& Monnai, 1993). Inhibitory activity was reduced after GMP digestion with chymotrypsin but inhibitory activity increased after GMP digestion with trypsin or pronase so the peptide chain must also participate. Inhibition of splenocyte proliferation by GMP was also observed against concanavalin A (Con A), phytohaemagglutinin-P (PHA) and pokeweed mitogen in addition to LPS (Otani et al. 1992; Otani \& Hata, 1995).

Otani et al. (1995) were also able to separate GMP into seven distinct fractions with up to five sialic acid groups containing one or two of the di-, tri- and tetrasaccharides shown above. The fractions inhibited both mouse splenocyte and rabbit Peyer's patch cell proliferation as follows:

(1) three fractions inhibited LPS-induced proliferation;

(2) five fractions, with activity in proportion to the number of sialic acids present, inhibited PHAinduced proliferation;

(3) none of the fractions inhibited Con A-induced proliferation.

Because of reduced inhibitory activity after chymotrypsin digestion, the researchers suggest that the Ser-149 phosphate plays a part in GMP binding to the mitogen receptor.

The investigation then turned to the mechanism by which GMP inhibits mitogens from inducing splenocyte proliferation. Cells were incubated with and without GMP. The cells were then immunostained with anti-к-casein antibody. Only the cells incubated with GMP retained the anti-кcasein antibody thus demonstrating that GMP adheres directly to the cell surface (Otani \& Monnai, 1995). Monnai \& Otani (1997) found that when cells were incubated with GMP, one of the cytokines in the interleukin-1 (IL-1) family, IL-1ra in particular, is synthesized. The IL-1ra blocks the action of IL-1 by binding to IL-1 receptors. Since IL-1 cannot bind to its receptors, it cannot trigger splenocyte proliferation and, in turn, an inflammatory response. In addition to the inhibition of LPS-induced binding of IL-1, they also showed that GMP binds to CD4 + T cells and suppresses PHA-stimulated expression of interleukin-2 (IL-2) receptor and inflammatory response
(Otani et al. 1996) and whereas GMP binds to CD4+T cells, it does not bind to CD8 + T cells.

Yun et al. (1996) studied the effect of GMP on immunoglobulins produced by LPS-stimulated splenocytes. They found that only the IgA concentration was increased by GMP and that only the population of surface IgApositive cells was increased by GMP. Snow Brand Milk Products (1996) was granted a patent on the use of bovine GMP for accelerating human B lymphocyte growth. In a culture test they showed that GMP accelerates proliferation of normal human B lymphocytes, but not T lymphocytes. This finding substantiates up-regulation of the humoral immune system.

\section{Future directions}

This review of the state of GMP research clearly shows that several potential clinical/commercial GMP applications exist. All the phenomena cited were observed in vitro or in animals. No reference relating to bovine GMP bioactivity in humans was found. Currently, only inference and extrapolation can be made concerning possible benefits of GMP. Reliable GMP applications in humans could benefit human health as well as provide technical support for functional food type claims for some products produced by the dairy industry. Some possibilities are as follows.

Prevention of bacterial infection and toxin binding is one area worthy of pursuit. Kawasaki et al. (1995) obtained a patent for use of GMP to neutralize endotoxin. Dosako et al. (1992) obtained a patent related to prevention of $E$. coli adhesion and protection against Epstein-Barr virus. A simpler approach may be feeding of whey protein products. If $1 \mathrm{mg}$ of GMP per day was enough to protect a mouse from bacterial toxins then one might imagine that between 0.5 and $1 \mathrm{~g}$ of GMP per day might protect a child. Since GMP is $15 \%$ of whey protein, $10-20 \mathrm{~g}$ of $35 \% \mathrm{WPC}$ would be needed at a cost of only $1.5-3$ cents (at $\$ 1.43$ / $\mathrm{kg}$ ). However, this approach may not be universally applicable. Neeser et al. (1988b) demonstrated that CFA/I and CFA/II E. coli require an N-linked rather than an Olinked saccharide. Since GMP contains O-linked saccharides it is not effective. It may be that intact GMP is ineffective as a protective agent because there are steric or charge-related factors which interfere with the binding of oligosaccharides to the bacterial receptor. Perhaps GMP could provide an inexpensive source for free oligosaccharides or synthetic oligosaccharide derivatives which would afford antibacterial protection.

The findings regarding gastrointestinal contraction are intriguing. Stan et al. (1983) proposed that reducing gastric secretions and stomach mixing would reduce proteolysis in young animals thus preserving milk-derived immunoglobulins, lactoferrin, and lysozyme and allowing them to pass through the stomach intact. These proteins could then provide protection in the intestines. If this premise could be extended to humans it would benefit infant feeding and immunocompromised patients

There are persistent reports of a modest growthpromoting effect by GMP for some bifidus species. Disaccharide II may be involved. Is this a situation where if one feeds more, one will obtain the desired effect? 
Perhaps, but Idota et al. (1994) present in vitro evidence that even that may not be effective as increasing the bovine GMP concentration from 0.01 to $1.0 \mathrm{mg} / \mathrm{ml}$ decreased its growth-promoting activity by as much as half. There is much more to be learned about bifidobacterial growthpromotion by GMP and trials in animals and humans are essential.

An extension of the GMP inhibited LPS-induced B lymphocyte proliferation and PHA-induced T lymphocyte proliferation would be down-regulation of the immune system or oral tolerance (Otani et al. 1992). This would afford a newborn animal a passive defence mechanism against a broad spectrum of environmental antigens. Could this be extended to allergy?

\section{Conclusion}

It is clear that GMP exhibits several useful biological activities. The most promising areas appear to be in protection from toxins, bacteria and viruses and in regulating the immune system. Articles have appeared in food processing magazines (Steijns, 1996; Clare, 1998; LaBell, 1998) extolling the benefits of GMP as a nutraceutical. Initial attempts to incorporate GMP into meringues, biscuits and apple jelly (Marshall, 1991) met with limited success. Snow Brand Milk Products (1999) has received a patent on a stabilizer/viscosifier which contains GMP. The increased interest due to health-promoting aspects of GMP will spark successful food use applications to take advantage of the biological activities.

\section{References}

Aleinik SI, Stan EYa \& Chernikov MP (1986) Study of the mechanism of acid secretion inhibition with $\kappa$-casein peptides in the stomach. Fiziologicheskii Zhurnal SSSR 72, 799-803.

Azuma N, Yamauchi K \& Mitsouka T (1985) Bifidius growthpromoting activity of a glycomacropeptide derived from human к-casein. Agricultural and Biological Chemistry 48, 21592162.

Berrocal R \& Neeser J-R (1993) Production of kappa-caseinoglycomacropeptide. United States Patent 5216129

Beucher S, Levenez F, Yvon M \& Corring T (1994a) Effect of gastric digestive products from casein on CCK release by intestinal cells in rat. Journal of Nutritional Biochemistry 5, 578-584.

Beucher S, Levenez F, Yvon M \& Corring T (1994b) Effect of caseinomacropeptide (CMP) on cholecystokinin (CCK) release in rat. Reproduction Nutrition Development 34, 613-614.

Bezkorovainy A, Grolich D \& Nichols JH (1979) Isolation of a glycopolypeptide fraction with Lactobacillus subspecies pennsylvanicus growth-promoting activity from whole human milk casein. American Journal of Clinical Nutrition 32, 1428-1432.

Chernikov MP \& Stan EYa (1982) Physiological activity of products of limited $\mathrm{\kappa}$-casein proteolysis. XXI International Dairy Congress 2, 161.

Clare R (1998) The benefits of CMP. Dairy Industries International 63, 29-31.

Coolbear KP, Elgar DF, Coolbear T \& Ayers JS (1996) Comparative study of methods for the isolation and purification of bovine $\mathrm{k}$-casein and its hydrolysis by chymosin. Journal of Dairy Research 63, 61-71.
Doi H, Ibuki F \& Kanamori M (1979) Hetrogeneneity of reduced bovine к-casein. Journal of Dairy Science 62, 195-293.

Doi H, Kobatake H, Fumio I \& Kanamori M (1980) Attachment sites of carbohydrate portions to peptide chain of $\kappa$-casein from bovine colostrum. Agricultural and Biological Chemistry 44, 2605-2611.

Dosako S, Nishiya T \& Deya E (1991) Process for the production of kappa-casein glycomacropeptide. United States Patent 5061622

Dosako S, Kusano H, Deya E \& Idota T (1992) Infection protectant. United States Patent 5147853

Eigel WN, Butler JE, Ernstrom CA, Farrell HM Jr, Harwalkar VR, Jenness R \& Whitney RMcL (1984) Nomenclature of proteins of cow's milk: fifth revision. Journal of Dairy Science 67, 1599-1631.

Erdman P \& Neumann AG (1999) Method for treating a lactic raw material containing GMP. European Patent 880902

Etzel MR (1999) Production of kappa-casein macropeptide. World Patent 9918808

Eustache J-M (1977a) Extraction of glycoproteins and sialic acid from whey. United States Patent 4042576

Eustache J-M (1977b) Extraction of glycoproteins and sialic acid from whey. United States Patent 4042575

Faure J-C, Schellenberg DA, Bexter A \& Wuerzner HP (1984) Barrier effect of Bifidobacterium longum on a pathogenic Escherichia coli strain by gut colonization in the germ-free rat. Zeitschrift fur Ernahrungswissenschaft 23, 41-51.

Fiat A-M, Alais C \& Jolles P (1972) The amino-acid and carbohydrate sequences of a short glycopeptide isolated from bovine к-casein. European Journal of Biochemistry 27, 408412.

Fiat A-M \& Jolles P (1989) Caseins of various origins and biologically active casein peptides and oligosaccharides: structural and physiological aspects. Molecular and Cellular Biochemistry 87, 5-30.

Fiat A-M, Jolles J, Loucheux-Lefebvre M-H, Alais C \& Jolles P (1981) Localization of the prosthetic sugar groups of bovine colostrum к-casein. Hoppe-Seyler's Zeitschrift fur Physiologische Chemie 362, 1447-1454.

Fournet B, Fiat A-M, Alais C \& Jolles P (1979) Cow к-casein: structure of the carbohydrate portion. Biochimica et Biophysica Acta 576, 339-346.

Fournet B, Fiat A-M, Montreuil J \& Jolles P (1975) The sugar part of $\kappa$-caseins from cow milk and colostrum and its microheterogeneity. Biochimie 57, 161-165.

Glasgow LR \& Hill RL (1980) Interaction of Mycoplasma gallisepticum with sialyl glycoproteins. Infection and Immunity 30, 353-361.

Guilloteau P, Chayvialle JA, Mendy F, Roger L, Toullec R, Bernard C, Mouats A \& Faverdin P (1987) Effect of caseinomacropeptide (CMP) on gastric secretion and plasma levels of digestive hormones in preruminant calves. Reproduction Nutrition Development 27, 287-288.

Guilloteau P, Le Huerou-Luron I, Chayviaille JA, Toullec R, Legeas M, Bernard C, Roger L \& Mendy F (1994) Effect of caseinomacropeptide (CMP) on gastric secretion and plasma gut regulatory peptides in preruminant calves. Reproduction Nutrition Development 34, 612-613.

Gyorgy P, Jeanloz RW, Hubertus von Nicolai \& Zilliken F (1974) Undialyzable growth factors for Lactobacillus bifidus var pennsylvanicus. European Journal of Biochemistry 43, 29-33.

Gyorgy P, Kuhn R, Rose CS \& Zilliken F (1954b) Bifidus factor. II. Its occurence in milk from different species and in other natural products. Archives of Biochemistry and Biophysics 48 , 202-208.

Gyorgy P, Norris RF \& Rose CS (1954a) Bifidus factor. I. A 
variant of Lactobacillus bifidus requiring a special growth factor. Archives of Biochemistry and Biophysics 48, 193-201.

Hollar CM, Law AJR, Dalgleish DG \& Brown RJ (1991) Separation of major casein fractions using cation-exchange fast protein liquid chromatography. Journal of Dairy Science 74, 2403-2409.

Holmgren J (1981) Actions of cholera toxin and the prevention and treatment of cholera. Nature 292, 413-416.

Idota T, Kawakami H \& Nakajima I (1994) Growth-promoting effects of $\mathrm{N}$-actylneuraminic acid-containing substances on Bifidobacteria. Bioscience, Biotechnology and Biochemistry 58, 1720-1722.

Idota T (1996) Sialylated compounds in human milk and their physiological significance in infants. Snow Brand $R \& D$ Reports 106, $1-55$.

Isoda H, Kawasaki Y, Tanimoto M, Dosako S \& Idota T (1999) Use of compounds containing or binding sialic acid to neutralize bacterial toxins. European Patent 385112

Jolles J, Schoentgen F, Alais C, Fiat A-M \& Jolles P (1972) Studies on the primary structure of cow K-casein - Structural features of para-к-casein; N-termianl sequence of $\kappa$-caseinoglycopeptide studied with a sequencer. Helvetica Chimica Acta 55, 2872-2883.

Jolles J, Fiat A-M, Alais C \& Jolles P (1973) Comparative study of cow and sheep $\kappa$-caseinoglycopeptides: determination of the $\mathrm{N}$-terminal sequences with a sequencer and location of the sugars. FEBS Letters 30, 173-176.

Kanamori M, Kawaguchi N, Ibuki F \& Doi H (1980) Attachment sites of carbohydrate moieties to peptide chain of bovine $\mathrm{\kappa}$ casein from normal milk. Agricultural and Biological Chemistry 44, 1844-1861.

Kawasaki Y \& Dosako S (1994) Process of producing к-casein glycomacropeptides. United States Patent 5278288

Kawasaki Y, Dosako S, Shimatani M \& Idota T (1994) Process for producing $\kappa$-casein glycomacropeptides. United States Patent 5280107

Kawasaki Y, Isoda K, Shinmoto H, Tanimoto M, Dosako S, Idota $\mathrm{T} \&$ Nakajima I (1993b) Inhibition by $\mathrm{\kappa}$-casein glycomacropeptide and lactoferrin of influenza virus hemaglutination. Bioscience, Biotechnology and Biochemistry 57, 1214-1215.

Kawasaki Y, Isoda H, Tanimoto M, Dosako S, Idota T \& Ahiko K (1992) Inhibition by lactoferrin and $\kappa$-casein glycomacropeptide of binding of cholera toxin to its receptor. Bioscience, Biotechnology and Biochemistry 56, 195-198.

Kawasaki Y, Kawakiami H, Tanimoto M, Dosako S, Tomizawa A, Kotake M \& Nakajima I (1993a) pH-dependent molecular weight changes of $\kappa$-casein glycomacropeptide and its preparation by ultrafiltration. Milchwissenschaft 48, 191-196.

Kawasaki I, Ykio K, Sunichi D \& Otani H (1995) Neutralizing agent for an endotoxin comprising a fraction containing $\mathrm{K}$ casein glycomacropeptide (GMP) as an active ingredient. Japanese Patent 7278013

Kehagias C, Jao YC, Micolajcik EM \& Hansen PMT (1977) Growth response of Bifidobacterium bifidum to a hydrolytic product isolated from bovine casein. Journal of Food Science 42, 146-150.

LaBell F (1998) Health-enhancing whey proteins. Prepared Foods 167, 143.

Leeden R (1966) The chemistry of gangliosides: a review. Journal of the American Oil Chemists Society 43, 57-66.

Liukkonen J, Haataja S, Tikkanen K, Kelm S \& Finne J (1992) Identification of $N$-acetylneuraminyl $\alpha 2-3$ poly- $N$-acteyl lactosamine glycans as the receptors of sialic acid-binding Streptococcus suis strains. Journal of Biological Chemistry 267, 21105-21111.

Loomes LM, Uemura K, Childs RA, Paulson JC, Rogers GN,
Scudder PR, Michalski JC, Housell EF, Taylor-Robinson D \& Feizi T (1984) Erythrocyte receptors for Mycoplasma pneumoniae are silaylated oligosaccharides of Ii antigen type. Nature 306, 560-563.

McKenzie HA \& Wake RG (1961) An improved method for the isolation of к-casein. Biochimica et Biophysica Acta 47, 240242.

Marshall SC (1991) Casein macropeptide from whey - a new product opportunity. Food Research Quarterly 51, 86-91.

Minkiewicz P, Slangen CJ, Lagerwerf FM, Haverkamp J, Rollema HS \& Visser S (1996) Reversed phase highperformance liquid chromatographic separation of bovine kappa-casein macropeptide and characterization of isolated fractions. Journal of Chromatography 743, 123-135.

Monnai M \& Otani H (1997) Effect of bovine к-caseinoglycopeptide on secretion of interleukin-1 family cytokines by P388D1 cells, a line derived from mouse monocyte/macrophage. Milchwissenschaft 52, 192-196.

Morr CV \& Seo A (1988) Fractionation and characterization of glycomacropeptide from caseinate and skim milk hydrolyzates. Journal of Food Science 53, 80-87.

Nakano T \& Ozimek L (1998) Gel chromatography of glycomacropeptide (GMP) from sweet whey on Sephacryl S200 at different pHs and on Sephadex G-75 in 6M guanidine hydrochloride. Milchwissenschaft 53, 629-633.

Neeser JR (1991a) Anti-plaque and anticaries agent. United States Patent 4994441

Neeser JR (1991b) Anti-plaque and anticaries agent. United States Patent 4992420

Neeser JR, Chambaz A, Hoang KY \& Link-Amster H (1988b) Screening for complex carbohydrates inhibiting hemaggluatinations by $\mathrm{CFA} / \mathrm{I}-$ and $\mathrm{CFA} / \mathrm{II}-$ expressing enterotoxigenic Escherichia coli strains. FEMS Microbiology Letters 49, 301-307.

Neeser JR, Chambaz A, Vedovo SD, Prigent MJ \& Guggenheim B (1988a) Specific and nonspecific inhibition of adhesion of oral actinomyces and streptococci to erythrocytes and polystrene by caseinoglycopeptide derivatives. Infection and Immunity 56, 3201-3208.

Neeser JR, Grafstrom RC, Woltz A, Brassart D, Fryder V \& Guggenheim B (1995) A $23 \mathrm{kda}$ membrane glycoprotein bearing NeuNac2-3Gal $\beta$ 1-3GalNAc O-linked carbohydrate chains acts as a receptor for Streptococcus sanguis OMZ 9 on human buccal epithelial cells. Glycobiology 5, 97-104.

Neeser JR, Golliard M, Woltz A, Rouvet M, Dillmann ML \& Guggenheim B (1994) In vitro modulation of oral bacterial adhesion to saliva-coated hydroxyapatite beads by milk casein derivatives. Oral Microbiology and Immunology 9, 193-201.

Nielsen P \& Tromholt N (1994) Method for production of a kappa-casein glycomacropeptide and use of a kappa-casein glycomacropeptide. World Patent 9415952

Ofek I \& Sharon N (1990) Adhesins as lectins: specificity and role in infection. Current Topics in Microbiology and Immunology 151, 91-113.

Otani H \& Hata I (1995) Inhibition of proliferative responses of mouse spleen lymphocytes and rabbit Peyer's patch cells by bovine milk caseins and their digests. Journal of Dairy Research 62, 339-348.

Otani H, Horimoto Y \& Monnai M (1996) Suppression of interleukin-2 receptor expression on mouse CD4 $+\mathrm{T}$ Cells by bovine $\mathrm{\kappa}$-caseinoglycopeptide. Bioscience, Biotechnology and Biochemistry 60, 1017-1019.

Otani H \& Monnai M (1993) Inhibition of proliferative responses of mouse spleen lymphocytes by bovine milk $\kappa$-casein digests. Food and Agricicultural Immunology 5, 219-229.

Otani H \& Monnai M (1995) Induction of an interleuken-1 receptor antagonist-like component produced from mouse 
speen cells by bovine $\mathrm{\kappa}$-caseinoglycopeptide. Bioscience, Biotechnology and Biochemistry 59, 1166-1168.

Otani H, Monnai M \& Hosono A (1992) Bovine $\kappa$-casein as inhibitor of the proliferation of mouse splenocytes induced by lipopolysaccharide stimulation. Milchwissenschaft 47, 512-515.

Otani H, Monnai M, Kawasaki Y, Kawakami H \& Tanimoto M (1995) Inhibition of mitogen-induced proliferative responses of lymphocytes by bovine $\mathrm{\kappa}$-caseinoglycopeptides having different carbohydrate chains. Journal of Dairy Research 62, 349357.

Parkkinen A, Rogers GN, Korhonen T, Dahr W \& Finne J (1986) Identification of the O-linked sialyloligosaccharides of glycophorin $\mathrm{A}$ as the erythrocyte receptors for S-fimbriated Escherichia coli. Infection and Immunity 54, 37-42.

Petschow BW \& Talbott RD (1991) Response of Bifidobacterium species to growth promoters in human and cow milk. Pediatric Research 29, 208-213.

Poch M \& Bezkorovainy A (1988) Growth-enhancing supplements for various species of the genus Bifidobacterium. Journal of Dairy Science 71, 3214-4221.

Poch M \& Bezkorovainy A (1991) Bovine milk к-casein trypsin digest is a growth enhancer for the genus Bifidobacterium. Journal of Agricultural and Food Chemistry 39, 73-77.

Proulx M, Gauthier SF \& Roy D (1992) Effect of casein hydrolysates on the growth of Bifidobacteria. Le Lait 72, 393-404.

Saito T \& Itoh T (1992) Variations and distributions of Oglycosidically linked sugar chains in bovine $\kappa$-casein. Journal of Dairy Science 75, 1768-1774.

Saito T, Itoh T \& Adachi S (1981) The chemical structure of a tetrasaccaride containing $\mathrm{N}$-acetylglucosamine obtained from bovine colostrum к-casein. Biochimica et Biophysica Acta $\mathbf{6 7 3}$, 487-494.

Saito T, Yamaji A \& Itoh T (1991) A new isolation method of caseinoglycopeptide from sweet cheese whey. Journal of Dairy Science 74, 2831-2837.

Schengrund C-L \& Ringler NJ (1989) Binding of Vibrio cholera toxin and the heat-labile enterotoxin of Escherichia coli to GM1, derivatives of GM1, and nonlipid oligosaccharide polyvalent ligands. Journal of Biological Chemistry 264, 13233-13237.

Schupbach P, Neeser JR, Golliard M, Rouvet M \& Guggenheim B (1996) Incorporation of caseinoglycomacropeptide and caseinophosphopeptide into the salivary pellicle inhibits adherence of mutans streptococci. Journal of Dental Research 75, 17791788 .

Shammet KM, McMahon DJ \& Brown RJ (1992) Characteristics of macropeptide fractions isolated from whole casein and purified к-casein. Milchwissenschaft 47, 615-619.

Sharma SK, Hill AR \& Mittal GS (1993) An improved method to measure glycomacropeptides (GMP) in renneted milk. Milchwissenschaft 48, 71-73.

Shimatini M, Uchida Y, Matsuno I, Oyoshi M \& Ishiyama Y (1993) Process for manufacturing sialic acids-containing composition. United States Patent 5270462

Simon PM (1996) Pharmaceutical oligosaccharides. Drug Discovery Today $1,522-528$.

Skudder PJ (1985) Evaluation of a porous silica-based ionexchange medium for the production of protien fractions from rennet- and acid-whey. Journal of Dairy Research 52, 167-181.

Snow Brand Milk Products Co (1996) Human normal B lymphocyte accelerating agent. Japanese Patent, 96018997

Snow Brand Milk Products Co (1999) Stabilizer for food manufacturing. Japanese Patent, 11103794
Stan EYa \& Chernikov MP (1979) On the physiological activity of $\mathrm{\kappa}$-casein glycomacropeptide. Voprosy Meditsinskoi Khimii 25, 348-352.

Stan EYa \& Chernikov MP (1982) Formation of a peptide inhibitor of gastric secretion from rat milk proteins in vivo. Byulleten' Eksperimental'noi Biologii I Metisiney 94, 64-66.

Stan EYa, Groisman SD, Krasil'shchikov KB \& Chernikov MP (1983) Effects of к-casein glycomacropeptide motility in dogs. Byulleten' Eksperimental'noi Biologii I Metisiney 96, 10-12.

Steijns J (1996) Dietary proteins as the source of new health promoting bio-active peptides with special attention to glutamine peptide. Food Tech Europe 3, 80-84.

Sugii S \& Tsuji T (1989) Binding and hemagglutinating properties of the B Subunit(s) of heat-labile enterotoxin isolated from human enterotoxigenic Escherichia coli. FEMS Microbiological Letters 66, 45-50.

Tanimoto M, Kawasaki Y, Shinmoto H, Dosako S \& Tomizawa A (1991) Process for producing $\kappa$-casein glycomacropeptide. United States Patent 5075424

Tran VD \& Baker BE (1970) Casein. IX. Carbohydrate moeity of к-casein. Journal of Dairy Science 53, 1009-1012.

van Halbeek H, Dorland L, Vliefenthart JFG, Fiat A-M \& Jolles P (1980) A 360-MHz 1H-NMR study of three oligosaccharides isolated from cow к-casein. Biochimica et Biophysica Acta 623 , 295-300.

van Heyningen S (1974) Cholera toxin: interaction of subunits with ganglioside GM1. Science 183, 656-657.

van Hooydonk ACM \& Olieman C (1982) A rapid and sensitive high-performance liquid chromatography method of following the action of chymosin in milk. Netherlands Milk and Dairy Journal 36, 153-158.

van Hooydonk ACM, Olieman C \& Hagedoorn HG (1984) Kinetics of the chymosin-catalyzed proteolysis of $\kappa$-casein in milk. Netherlands Milk and Dairy Journal 37, 207-222.

Vasilevskaya LS, Stan EYa, Chernikov MP \& Shlygin GK (1977) Inhibitory action of glycomacropeptide produced on the gastric secretion by various humoral stimulants. Voprosy Pitaniya 2124.

Whitney RM (1988) Proteins in milk. In Fundamentals of Dairy Chemistry, pp. 89-92 [NP Wong, R Jenness, M Keeney and EH Marth, editors]. New York: Van Nostrand Reinhold.

Worobo R, Kim BC, Kim S \& Rheem S (1998) Detection of cholera-toxin-binding activity of glycomacropeptide from bovine $\kappa$-casein and optimization of its production by use of response surface methodology. Journal of Dairy Science, Supplement 1 81, 18.

Yaguchi M, Davies DT \& Kim YK (1968) Preparation of k-casein by gel filtration. Journal of Dairy Science 51, 473-477.

Yakabe T, Kawakami H \& Idota T (1994) Growth simulation agent for bifidus and lactobacillus. Japanese Patent 7267866

Yun SS, Sugita-Konishi Y, Kumagai S \& Yamauchi K (1996) Glycomacropeptide from cheese whey protein concentrate enhances IgA production by lipopolysaccharide-stimulated spleen cells. Animal Science and Technology (Japan) 67, 458-462.

Yvon M, Beucher S, Guilloteau P, Huerou-Luron IL \& Corring T (1994) Effects of caseinomacropeptide (CMP) on digestion regulation. Reproduction Nutrition Development 34, 527-537.

Zhang YP \& Shapiro P (1998) Fluoride free dental remineralization. World Patent 9852524

Zittle CA \& Custer JH (1963) Purification and some of the properties of $\alpha_{\mathrm{S}}$-casein and $\kappa$-casein. Journal of Dairy Science 46, $1183-1188$. 